\title{
Miyokard İnfarktüsü Geçirmiş Hastalarda Algılanan Stresin Belirlenmesi
}

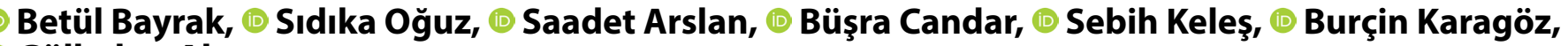 \\ Gülbahar Akpınar
}

Marmara Üniversitesi Sağlık Bilimleri Fakültesi, İç Hastalıkları Hemşireliği Anabilim Dalı, İstanbul

\begin{abstract}
Özet
Amaç: Bu araştırma Miyokart İnfarktüsü (Mi) geçirmiş hastalarda algılanan stresin belirlenmesi amacıyla tanımlayıcı olarak planlandı.

Yöntemler: Araştırma, İstanbul ilinde bir eğitim ve araştırma hastanesinin kardiyoloji servislerinde Ocak-Mayıs 2019 tarihleri arasında yatan $300 \mathrm{Mi}$ geçirmiş hasta ile yapıldı. Veriler "Anket Formu" ve "Algılanan Stres Ölçeği-14 (ASÖ-14)" kullanılarak toplandı. Verilerin analizinde tanımlayıcı istatistikler, One-way ANOVA ve paired sample t testi kullanıldı.

Bulgular: Araştırmaya katılan hastaların yaş ortalaması $61.84 \pm 14$ olup, \%67.3'ü erkektir. Hastaların \%82.3'ünün komorbid hastalığı, \%64.7'sinin hipertansiyonu, \%44.3'ünün diyabeti vardır ve \%56.7'si ilk kez Mi geçirmiştir. Mi geçirdikten sonra hastaların \%54.8' inin endişeli, \%55' inin stresli olduğu belirlendi. Çalışmaya katılan hastaların algılanan stres puan ortalaması $25.94 \pm 6.86$ bulundu. Eğitim seviyesi ve geliri düşük, komorbid hastalığı, diyabeti ve hipertansiyonu olan ve düzenli ilaç kullanmayan hastaların algılanan stres puanı anlamlı düzeyde yüksek bulundu $(p<0.05)$. Ayrıca hobisi olmayan, fiziksel aktivite yapmayan ve Mi sonrası kendini endişeli hisseden hastaların algılanan stres puanı anlamlı düzeyde yüksek bulundu $(\mathrm{p}<0.05)$.

Sonuç: Çalışmaya katılan hastaların stres düzeyi normal olup stresle başa çıkabildikleri tespit edildi. Düşük gelir, komorbid hastalık, hipertansiyon, diyabet, düzenli ilaç kullanmamak, hobinin olmaması, fiziksel aktivite yapmamak algılanan stres düzeyini arttırmaktadır.
\end{abstract}

Anahtar sözcükler: Algılanan stres; hemşirelik; miyokart infarktüsü; stres.

\section{Determination of Perceived Stress in Patients with Myocardial Infarction}

\begin{abstract}
Objective: This study was planned to determine perceived stress in patients with myocardial infarction.

Methods: The study was conducted with 300 patients with myocardial infarction who were hospitalized in the cardiology department of a training and research hospital in Istanbul between January-May 2019. Data were collected using "Questionnaire" and "Perceived Stress Scale-14 (AS-14)". Descriptive statistics, One-way ANOVA and paired sample t test were used for data analysis.

Results: The mean age of the patients was $61.84 \pm 14$ and $67.3 \%$ were male. Of the patients, $82.3 \%$ had comorbid disease, $64.7 \%$ had hypertension, $44.3 \%$ had diabetes, and $56.7 \%$ had myocardial infarction for the first time. After myocardial infarction, $54.8 \%$ of the patients were anxious and 55\% were stressful. Mean perceived stress score of the patients included in the study was $25.94 \pm 6.86$. Perceived stress scores of the patients with low education level and income, comorbid disease,
\end{abstract}

İletişim (Correspondence): Araş. Gör. Uzm. Betül Bayrak. Marmara Üniversitesi Sağlık Bilimleri Fakültesi, İç Hastalıkları Hemşireliği Anabilim Dalı, İstanbul, Turkey

Telefon (Phone): +90 5393771786 E-Posta (E-mail): bayrak.betul@yahoo.com

Başvuru Tarihi (Submitted Date): 07.11.2019 Kabul Tarihi (Accepted Date): 06.12.2019

oCopyright 2019 by Turkish Society of Cardiology - Available online at www.anatoljcardiol.com 
diabetes and hypertension who did not use regular medication were found significantly higher $(p<0.05)$. In addition, the perceived stress scores of the patients without hobby, not doing physical activity and feeling anxious after myocardial infarction were significantly higher $(p<0.05)$.

Conclusion: The stress level of the patients participating in the study was normal and they were able to cope with stress. Low income, comorbid disease, hypertension, diabetes, not using regular medication, lack of hobby, and lack of physical activity increase perceived stress level.

Keywords: Myocardial infarction; nursing; percieved stress; stress.

Cite this article as: Bayrak B, Oğuz S, Arslan S, Candar B, Keleş S, Karagöz B, et al. Determination of Perceived Stress in Patients with Myocardial Infarction. Turk J Cardiovasc Nurs 2019;10(23):129-137.

$\mathrm{D}$ ünya Sağlık Örgütü (DSÖ) istatistiklerine göre 2016 yılında meydana gelen 56.9 milyon ölümün yarısından çoğunun (\%54) ilk 10 nedeni arasında iskemik kalp hastalığı birinci sırada yer almaktadır. ${ }^{[1]}$ Türkiye İstatistik Kurumu (TÜIK) 2018 yılı verilerine bakıldığında tüm ölüm vakalarının (423 bin) \%38.4'ünün (162 bin) sebebi ile birinci sırada dolaşım sistemi hastalıkları yer almaktadır. Dolaşım sistemi hastalıklarına bağlı ölümlerin \%39.7'sini ise iskemik kalp hastalığı oluşturmaktadır. ${ }^{[2]}$ İskemik kalp hastalığının ilk belirtisi olan Mi patolojik olarak uzun süreli hücre iskemisine bağlı koroner damarların miyokard kasında meydana gelen doku ölümüdür. ${ }^{[3,4]}$ Koroner arter hastalığı (KAH) olarak bilinen miyokard infarktüsünün ${ }^{[3]}$ değiştirilemeyen risk faktörleri yaş, cinsiyet ve birinci derece akrabada KAH öyküsüdür. Dislipidemi, hipertansiyon, diabetes mellitus, sağlıksız beslenme, hareketsiz yaşam, sigara kullanımı ${ }^{[5,7]}$ ve stres değiştirilebilir risk faktörleridir. ${ }^{[6,7]}$ Stres, değiştirilebilirse KAH insidansını azaltabileceği düşünülen psikososyal bir risk faktörü olarak bildirilmiştir. ${ }^{[9]}$ ikincil düzey değiştirilebilir risk faktörü olan stres bireylerin aşırı uyarıcı olaylar karşısında biyolojik, psikolojik ve sosyal açıdan homeostazisini zorlayıp başetme yeteneğini azaltan hormanal bir tepki mekanizmasıdır. Bireyin ani kriz ve travmatik olaylara karşı oluşturduğu öncelikle fizyolojik olaylardan etkilenen bilişsel, davranışsal, duygusal şemaları kapsayarak meydana gelen farklı bir mekanizmadan oluşmaktadır. ${ }^{[8]}$ Bu mekanizmanın merkezinde çeşitli duygusal tepkilerle ilişkili olarak çalışan hipotalamus yer almaktadır. Hipotalamus otonom sinir sistemini kontrol ederek hipofiz bezini aktive eder. Otonom sinir sistemi stres anında adrenalin akışını sağlayarak bazı hormonların (epinefrin ve nörepinefrin) serbest bırakılması için sinyal gönderir. Tirotropik hormon (TTH), tiroit bezini stimüle edip adrenokortikotropik hormonu (ACTH) dolaşım sistemine katar ve adrenal korteksi uyarır. Bu metabolik mekanizmanın sonucunda ise stresli şartlar göz önüne alındığında solunum hızlanır ve derinleşir, kalp atışları artar, kan damarları vazokonstriksiyona uğrayarak kan basıncının artmasına neden olur. ${ }^{[8]}$ Diğer bir deyişle, sempatik sinir sistemi strese yanıt olarak damarlarda vazo- konstriksiyon yapar ve damarlarda meydana gelen diğer otonomik tepkilerin bir sonucu olarak hipertansiyon gelişir. ${ }^{[6]}$ Hipertansiyon $\mathrm{KAH}$ nedeni olarak bilinen aterosklerozun gelişimine katkı sağlamakla birlikte ateroskleroz gelişmiş koroner arterlerin oksijen ihtiyacını ve buna bağıı Mi geçirme riskini arttırır. Strese bağlı hipertansiyon gelişebileceği gibi depresyon da ortaya çıkabilir. ${ }^{[9]}$ Majör depresyon ile stres arasında güçlü bir bağ vardır. Depresyon sonucu psikostresörler ve sosyal ilişkilerde bozulmaya bağlı kardiyovasküler hastalıklara yakalanma oranı ve ölüm riski artar. ${ }^{[10]}$ Psikolojik sorunlar kalbi etkileyebileceği gibi kalpteki birtakım sorunlar da insan psikolojisini etkileyerek şekillendirebilir. Kalp hastalığı tanısı alan birçok hastada ani ölüm hissi onların üzerinde anksiyete ve depresyon etkisi yaparak strese girmelerine neden olur. ${ }^{[11]}$

Kardiyovasküler kalp hastalıklarından herhangi birine sahip bir kişinin hastalığını öğrendikten sonraki ruhsal durumu ilerleyen yıllarda yeni kalp hastalıklarına sebebiyet verebildiği bildirilmektedir. ${ }^{[12]}$ Kalp hastalarında kişilik özelliklerinin hastalık öncesi dönemde hastalanma riskini arttırması ve iyileşme döneminde ise bu sürecin etkilenmesinde önemli bir rol oynadığı belirtilmektedir. ${ }^{[13]}$ Stres yönetimini sağlayamayan kişilik yapısına sahip bireylerde kalp hastalıklarına yakalanma oranı ve buna bağlı ölüm riski yüksektir. ${ }^{[14]}$ Psikososyal stresin kontrol altına alınmasının koroner olaylara olan etkisini değerlendirmek, stresin ölçülme zorluğu nedeniyle oldukça güç bir durumdur. Özellikle Mi geçirmiş bireylerde stresi azaltıcı girişimlerin yeni bir koroner olay gelişme riskini azaltabileceği bilinmektedir. ${ }^{[9]}$

Psikososyal faktörler koroner olaylara ve Mi sonrası iyileşmeyi geciktirmeye neden olan giderek artan derecede önemli risk faktörü olarak belirtilmektedir. Mental stres bireyin iyileşmesini geciktirebileceği gibi tekrar Mi geçirme riskini de arttırabilir. Aynı zamanda stres hastalığa uyumu da zorlaştırabilir. Hastalığa uyumu arttırmak, bireyin stres nedenlerini belirlemek ve bunların en aza indirilmseni sağlamak veya ortadan kaldırmak Mi geçirmiş bireyin hastaneye tekrar yatışını önleyebilir ve iyileşmesini olumlu yönde etkiler. 
Literatürde, Mi geçirmiş bireylerde algılanan stresin belirlenmesine yönelik yurt dışında yapılmış birkaç çalışma olmasına rağmen ülkemizde yapılmış çalışmaya rastlanmamıştır. Genellikle bu hastaların depresyon ve umutsuzluk düzeylerini inceleyen çalışmalar bulunmaktadır. Aslında stres devamında deprosyana ve umutsuzluğa neden olan kaygı içeren endişe halidir. Stresin ortadan kaldırılması veya etkileyen faktörlerin belirlenmesi bu durumların da önüne geçebilir. Bu nedenle, bu araştırma Mi geçirmiş hastalarda algılanan stresin belirlenmesi amacıyla planlanmıştır. Bu çalışma ile Mi geçirmiş hastaların algıladıkları stres düzeyi ve etkileyen faktörlerinin belirlenmesi literatüre önemli katkı sağlayacaktır.

\section{Gereç ve Yöntem}

Araştırmanın amacı ve tipi: $\mathrm{Bu}$ araştırma, $\mathrm{MI}$ geçirmiş hastalarda algılanan stresin belirlenmesi amacıyla tanımlayıcı ve kesitsel olarak planlandı.

Araştırma Soruları: Mi hastalarının algıladıkları stresin düzeyi nasıldır? Mi geçirmiş hastalarda sosyodemografik ve hastalık ile ilgili özelliklere göre algılanan stres düzeyi değişir mi?

Araştırmanın Yeri ve Zamanı: Araştırma Ocak - Mayıs 2019 tarihleri arasında İstanbul'da bir eğitim ve araştırma hastanesinin kardiyoloji kliniklerinde gerçekleştirildi.

Araştırmanın Evreni ve Örneklem Seçimi: Araştırma evrenini, İstanbul'da bir eğitim ve araştırma hastanesinin kardiyoloji kliniklerinde yatan $\mathrm{Mi}$ geçiren hastalar, örneklemini ise basit rastgele örnekleme yöntemi kullanılarak seçilen Mi geçirmiş, iletişim problemi olmayan ve çalışmaya katılmayı kabul eden 300 hasta oluşturdu.

Veri Toplama Araçları: Verilerin toplanmasında sosyodemografik özelliklerin belirlenmesi için "Anket Formu" ve Algılanan stresin belirlenmesi için "Algılanan Stres Ölçeği (ASÖ-14)" kullanıldı.

Anket Formu: Hasta tanılama formu, Mi geçiren hastalarda algılanan stresin belirlenmesine yönelik değişkenleri (kişisel özellikler ve hastalıkla ilgili özellikler) içeren ve iki bölümden oluşmaktadır. Formun birinci bölümünde kişisel özellikler (hastanın yaşı, cinsiyeti, eğitim durumu, medeni durumu, aile yapısı, gelir durumu, mesleği) değerlendirilirken, ikinci bölümünde hastalıkla ilgili özellikler (sigara-alkol kullanımı, kronik hastalığın varlığı, düzenli ilaç kullanımı, fiziksel aktivite yapma durumu, kişilik yapısı, kaç defa Mi geçirdiği, Mi geçirdikten sonra kendisini nasıl hissettiği) ele alındı.

Algılanan Stres Ölçeği: Algılanan Stres Ölçeği (ASÖ-14), Cohan, Kamarck ve Mermalstein (1983) tarafından geliştiril- miştir. Toplam 14 maddeden oluşan ASÖ-14 kişinin hayatındaki bir takım durumların ne derecede stresli algılandığını ölçmek için tasarlanmıştır. Katılımcılar her maddeyi “Hiçbir zaman (0)" ile "çok sıkıcı (4)" arasında değişen 5'li likert tipi ölçek üzerinde değerlendirmektedir. Maddelerden olumlu ifade içeren 7'si tersten puanlanmaktadır. ASÖ-14 puanları 0 ile 56 arasında değişmektedir. Yüksek puan kişinin stres algısının fazlalığına işaret etmektedir. 0-35 puan aralığı normal stres düzeyi olarak tanımlanmaktadır. Bireyin stresle etkili bir şekilde baş edebildiğini gösterir. 35-56 puan aralığında bireyin stres altında olduğunu ve stres ile etkili bir şekilde baş edemediğini gösterir. ASÖ-14 öz-yeterlilik ve stres algısı olmak üzere 2 faktörden oluşmaktadır. Türkçe ASÖ-14' geçerlilik geçerlilik ve güvenilirliği Esin ve ark. Tarafından 2013 yılında yapılmıştır. ${ }^{[10]}$

Veri Toplama Araçlarının Uygulanması: Araştırmaya başlamadan önce bir üniversitenin Sağlık Bilimleri Enstitüsü' nden etik kurulu onayı alındı (17.12.2018-231). Etik kurul onayı alındıktan sonra uygulamanın yapılacağı hastaneden kurum izni alındı. Kurum izni alınan hastanenin kardiyoloji kliniğinde yatan Mi geçiren hastalara araştırma hakkında detaylı bilgi verildikten ve çalışmaya katılmayı kabul eden hastaların yazılı ve sözlü onamları alındıktan sonra Anket Formu ve Algılanan Stres Ölçeği (ASÖ) yüz yüze görüşülerek dolduruldu. Verilerin araştırmacılar tarafından doldurulması 15-20 dk. sürmüştür.

Verilerin İstatiksel Analizi: Araştırmadan elde edilen veriler SPSS (Statistical Package for Social Sciencess) paket programı kullanılarak değerlendirildi. Değerlendirmede istatistiksel yordam olarak sayı, yüzde, ortalama ve standart sapma kullanıldı. Bağımlı değişkenlerin tanımlayıcı özelliklere göre normal dağılım gösterip göstermediğini belirlemek üzere Shapiro-Wilks Normality testi uygulandı. Verilerin analizinde parametrik yöntemler olarak bağımsız iki grup arasında niceliksel sürekli verilerin karşılaştırılmasında İndependent Sample t testi, ikiden fazla bağımsız grup arasında niceliksel sürekli verilerin değerlendirilmesinde tek yönlü (One Way) Anova testi kullanıldı. Anova testi sonrasında farklılıkları belirlemek üzere tamamlayıcı Post-hoc analizi olarak Benferroni testi kullanıldı. Elde edilen bulgular $\mathrm{p}<0.05$ anlamlılık düzeyinde değerlendirildi.

Araştırmanın Sınırlılıkları: Araştırmanın bir hastanenin kardiyoloji kliniğinde yatan Mi hastaları ile yapılmış olması tüm evrene genellenemez. Ayrıca araştırmaya katılmayı kabul eden bireylerin, Mi geçirdikten sonra algılanan stresin belirlenmesi için bireysel bildirim yöntemi ile veri toplamaya bağıı yanıtların doğruluğu katılımcıların bildirimleri ile sınırlıdır. 


\section{Bulgular}

\section{Mi Geçirmiş Hastaların Tanımlayıcı Özellikleri}

Sosyodemografik özellikler: Elde edilen verilere göre hastaların yaş ortalaması $61.84 \pm 14$ (Min 20, maks 94) olup, hastaların \%59.2'sinin 18-65 yaş aralığında olduğu, \%29.3'ünün 66-80 yaş aralığında olduğu, \%67.3'ünün erkek olduğu, \%72'sinin evli olduğu, \%49.3'ünün ilkokul mezunu olduğu, \%71'inin çekirdek aile ile yaşamakta olduğu, \%74.3'ünün gelir durumunun orta olduğu, \%74'ünün çalışmadığı ve \%40'ının emekli olduğu tespit edildi.

Hastalık ile ilgili özellikler: Hastaların \%82.3'ünün komorbid hastalığının olduğu, \%64.7'sinin hipertansiyonunun olduğu, \%44.3'ünün diabetes mellitusü olduğu, \%17.3'ünün böbrek yetersizliğinin olduğu, \%27.7'sinde kalp yetersizliği olduğu ve \%56.7'sinin bir kez Mi geçirdiği belirlendi (Tablo 1).

Hastaların kişilik özellikleri: Hastaların \%71.3'ünün yal- nızlık korkusu yaşamadığı, \%51.3'ünün hobisinin olmadığı, \%56'sının fiziksel aktivite yapmadığı, \%51'inin duygusal kişilik yapısına sahip olduğu görüldü. Mi sonrası hastaların \%55'inin stresli, \%48.3'ünün korkulu ve \%45.2'sinin ise endişeli olduğu bulundu (Tablo 2).

\section{Mi Geçiren Hastaların ASÖ-14 Puan Ortalamalarının Tanımlayıcı Özelliklerine Göre Değerlendirilmesi}

ASÖ-14'den alınabilecek Minimum puan 0 ve maksimum puan 56 'dır. Yapılan çalışmada hastaların ölçekten aldığı Minimum puan 8, maksimum puan 41 olup ASÖ-14 puan ortalamaları $25.94 \pm 6.86$ 'dır. Hastaların yaş, cinsiyet, medeni durum ve aile yapısına göre ASÖ-14 puan ortalamaları arasında anlamlı fark bulunmadı ( $p>0.05$ ). Hastaların eğitim durumlarının algılanan stres ölçeğinin ortalama puanına etkisi incelendiğinde, üniversite mezunu hastalar (22.52 \pm 6.91$)$ ile okur yazar $(28.04 \pm 6.81)$ ve ilkokul mezunu

\begin{tabular}{|c|c|c|c|}
\hline Tanımlayıcı Özellikler & Sayı (\%) & Hastalık ile İlgili Özellikler & Sayı (\%) \\
\hline Yaş (61.84 $\pm 14 ;$ Min: 20 ; maks: 94) & & Sigara kullanımı & \\
\hline $18-65$ & $180(59.2)$ & Evet & $91(30.3)$ \\
\hline $66-80$ & $89(29.3)$ & Hayır & $209(69.7)$ \\
\hline $81-100$ & $31(10.2)$ & Alkol kullanımı & \\
\hline Cinsiyet & & Evet & $30(10)$ \\
\hline Kadın & $98(32.3)$ & Hayır & $270(90)$ \\
\hline Erkek & $202(67.3)$ & Ek hastalık & \\
\hline Medeni durum & & Var & $247(82.3)$ \\
\hline Evli & $216(72)$ & Yok & $53(17.7)$ \\
\hline Bekar & $84(28)$ & Hipertansiyon & \\
\hline Eğitim durumu & & Var & $194(64.7)$ \\
\hline Okuryazar değil & $30(10)$ & Yok & $106(35.3)$ \\
\hline Okuryazar & $24(8)$ & Diabetes mellitus & \\
\hline Illkokul mezunu & $148(49.3)$ & Var & $133(44.3)$ \\
\hline Ortaokul mezunu & $61(20.3)$ & Yok & $167(55.7)$ \\
\hline Üniversite mezunu & $37(12.3)$ & Böbrek yetersizliği & \\
\hline Aile yapısı & & Var & $52(17.3)$ \\
\hline Yalnız & $26(8.7)$ & Yok & $248(82.7)$ \\
\hline Çekirdek aile & $213(71)$ & Kalp yetersizliği & \\
\hline Geniş aile & $61(20.3)$ & Var & $83(27.7)$ \\
\hline Gelir durumu & & Yok & $217(72.3)$ \\
\hline Gelir giderden az & $67(22.3)$ & Mi geçirme sayısı & \\
\hline Gelir gidere eşit & $223(74.3)$ & 1 & $170(56.7)$ \\
\hline Gelir giderden fazla & $10(3.3)$ & $2-3$ & $110(36.7)$ \\
\hline Kimle yaşıyorsunuz & & 4 ve üzer & $20(6.7)$ \\
\hline Aile & $252(84)$ & Düzenli ilaç kullanımı & \\
\hline Tek başına & $44(14.7)$ & Evet & $235(78.3)$ \\
\hline Yardımcı & $4(1.3)$ & Hayır & $65(21.7)$ \\
\hline Çalışma durumu & & Fiziksel aktivite & \\
\hline Evet & $78(26)$ & Evet & $132(44)$ \\
\hline Hayır & $222(74)$ & Hayır & $168(56)$ \\
\hline
\end{tabular}




\begin{tabular}{|c|c|c|c|}
\hline Kişilik Özellikleri & Sayı (\%) & Mi Sonrası Duygudurum & Sayı (\%) \\
\hline Yalnızlık korkusu & & Endişeli & \\
\hline Evet & $86(28.7)$ & Evet & $164(54.8)$ \\
\hline Hayır & 214 (71.3) & Hayır & $136(45.2)$ \\
\hline Hobi varlığı & & Öfkeli & \\
\hline Evet & $146(48.7)$ & Evet & $65(21.7)$ \\
\hline Hayır & $154(51.3)$ & Hayır & $235(78.3)$ \\
\hline İçe Dönük & & Depresif & \\
\hline Evet & $94(31.3)$ & Evet & $60(20)$ \\
\hline Hayır & $206(68.7)$ & Hayır & $240(80)$ \\
\hline Duygusal & & Stresli & \\
\hline Evet & $155(51.7)$ & Evet & $165(55)$ \\
\hline Hayır & $145(48.3)$ & Hayır & $135(45)$ \\
\hline
\end{tabular}

\begin{tabular}{|c|c|c|c|c|c|}
\hline Özellikler & Ort. $\pm S S$ & Min.-Maks. & $\mathbf{p}$ & Test değeri & Post hoc \\
\hline \multicolumn{6}{|l|}{ Yaş } \\
\hline $18-65$ & $26.13 \pm 6.81$ & $18-65$ & $* *$ & & \\
\hline $66-80$ & $25.85 \pm 6.64$ & $66-80$ & 0.666 & 0.319 & \\
\hline $81-100$ & $25.06 \pm 7.89$ & $81-100$ & & & \\
\hline Cinsiyet & & & * & & \\
\hline Kadın & $26.15 \pm 6.91$ & $10-41$ & 0.440 & 0.774 & \\
\hline Erkek & $25.50 \pm 6.76$ & $8-39$ & & & \\
\hline \multicolumn{6}{|l|}{ Eğitim durumu } \\
\hline Okur yazar değil & $25.60 \pm 6.75$ & $14-37$ & & & \\
\hline Okur yazar & $28.04 \pm 6.81$ & $17-39$ & ** & & \\
\hline Illkokul mezunu ${ }^{b}$ & $26.52 \pm 6.82$ & $13-41$ & 0.21 & 2.698 & $a-c * * *(p=0.038)$ \\
\hline Ortaokul mezunu & $26.00 \pm 6.512$ & $10-39$ & & & $b-c^{* * *}(p=0.034)$ \\
\hline Üniversite mezunuc & $22.52 \pm 6.91$ & $8-37$ & & & \\
\hline Diğer & $21.75 \pm 7.27$ & $12-29$ & & & \\
\hline Medeni durum & & & * & & \\
\hline Evli & $25.98 \pm 6.92$ & $8-41$ & 0.882 & 0.149 & \\
\hline Bekar & $25.85 \pm 6.74$ & $13-39$ & & & \\
\hline \multicolumn{6}{|l|}{ Aile yapısı } \\
\hline Yalnız & $24.54 \pm 6.91$ & $12-41$ & $* *$ & & \\
\hline Çekirdek & $26.19 \pm 7.04$ & $8-41$ & 0.484 & 0.727 & \\
\hline Geniş aile & $25.67 \pm 6.17$ & $14-38$ & & & \\
\hline \multicolumn{6}{|l|}{ Gelir durumu } \\
\hline Düşük ${ }^{a}$ & $27.07 \pm 6.54$ & $13-41$ & $* *$ & & \\
\hline Orta & $25.83 \pm 6.88$ & $8-41$ & 0.023 & 3.826 & $a-b * * *(p=0.019)$ \\
\hline Yüksek ${ }^{b}$ & $20.80 \pm 6.51$ & $12-33$ & & & \\
\hline Çalışma durumu & & & $*$ & & \\
\hline Evet & $25.59 \pm 6.95$ & $8-41$ & 0.601 & -5.24 & \\
\hline Hayır & $26.06 \pm 6.84$ & $10-41$ & & & \\
\hline
\end{tabular}

ASÖ: Algılanan Stres Ölçeği; n: katılımcı sayısı; Ort.: ortalama; SS: standart sapma; *: Independent Sample t Testi; **: One way ANOVA; ***Post-hoc analizine göre farklılığı yaratan gruplar.

(26.52 \pm 6.82 ) hastaların ASÖ-14 puan ortalamaları arasında istatistiksel olarak anlamlı fark olduğu bulundu $(p<0.05)$. Ayrıca düşük gelire sahip olan hastaların ASÖ-14 puan ortalaması (27.07 \pm 6.54$)$ ile yüksek gelire sahip hastaların ASÖ-14 puan ortalaması ( $25.85 \pm 6.74)$ arasında istatistiksel olarak anlamlı fark olduğu tespit edildi $(p<0.05)$ (Tablo 3 ). 


\begin{tabular}{|c|c|c|c|c|}
\hline Değişkenler & Ort. \pm SS & Min.-Maks. & $\mathbf{p}$ & F ya da $t$ \\
\hline Sigara kullanımı & & & * & \\
\hline Kullanıyor & $25.44 \pm 6.84$ & $10-41$ & 0.405 & -0.834 \\
\hline Kullanmiyor & $26.16 \pm 6.83$ & $8-41$ & & \\
\hline Alkol kullanımı & & & $*$ & \\
\hline Kullanıyor & $24.70 \pm 7.20$ & $10-40$ & 0.303 & -1.032 \\
\hline Kullanmıyor & $26.06 \pm 6.83$ & $8-41$ & & \\
\hline Hipertansiyon & & & * & \\
\hline Var & $26.53 \pm 6.99$ & $10-41$ & 0.045 & 2.012 \\
\hline Yok & $24.87 \pm 6.50$ & $8-41$ & & \\
\hline Diabetes mellitus & & & * & \\
\hline Var & $26.94 \pm 6.72$ & $8-40$ & 0.024 & 2.269 \\
\hline Yok & $25.14 \pm 6.88$ & $12-41$ & & \\
\hline Kalp yetersizliği & & & $*$ & \\
\hline Var & $26.73 \pm 7.27$ & $10-40$ & 0.215 & 1.243 \\
\hline Yok & $25.64 \pm 6.69$ & $8-41$ & & \\
\hline Böbrek yetersizliği & & & * & \\
\hline Var & $25.40 \pm 7.01$ & $14-41$ & 0.536 & -0.619 \\
\hline Yok & $26.35 \pm 6.84$ & $8-41$ & & \\
\hline Komorbid hastalık & & & $*$ & \\
\hline Var & $26.36 \pm 6.77$ & $8-41$ & 0.029 & 2.192 \\
\hline Yok & $24.09 \pm 7.07$ & $12-41$ & & \\
\hline Mì sayısı & & & $* *$ & \\
\hline Bir & $25.45 \pm 6.76$ & $12-41$ & 0.140 & 1.981 \\
\hline $2-3$ & $26.22 \pm 6.97$ & $8-41$ & & \\
\hline 4 ve üzeri & $28.55 \pm 6.74$ & $19-40$ & & \\
\hline Düzenli ilaç kullanımı & & & * & \\
\hline Evet & $24.46 \pm 6.72$ & $12-41$ & 0.049 & 1.973 \\
\hline Hayır & $26.35 \pm 6.85$ & $8-41$ & & \\
\hline Fiziksel aktivite & & & * & \\
\hline Evet & $24.95 \pm 7.07$ & $10-39$ & 0.027 & -2.221 \\
\hline Hayır & $26.71 \pm 6.60$ & $8-41$ & & \\
\hline
\end{tabular}

ASÖ: Algılanan Stres Ölçeği; n: katılımcı sayısı; Ort: ortalama; SS: standart sapma; *: Independent Sample t Testi; ${ }^{* *}$ : One-way Anova.

\section{Mi Geçiren Hastaların ASÖ-14 Puan Ortalamalarının Hastalık ile İlgili Özelliklerine Göre Değerlendirilmesi}

Sigara içme ve alkol kullanma durumunun, komorbid hastalık durumuna göre ise kalp yetersizliği ve böbrek yetersizliği bulunmasının ve Mi geçirme sayısının ASÖ-14 puan ortalamasını etkilemediği bulundu ( $p>0.05)$. Hipertansiyonu olan hastaların ASÖ-14 puan ortalaması (26.53 \pm 6.99 ), hipertansiyonu olmayan hastalara $(24.87 \pm 6.50)$ göre yüksek olup aralarında anlamlı fark olduğu bulundu $(p<0.05)$. Diyabeti olan hastaların ASÖ-14 puan ortalamaSI (26.94 \pm 6.72$)$ diyabeti olmayan hastalara $(25.14 \pm 6.88)$ göre yüksek ve aralarında anlamlı fark olduğu tespit edildi $(p<0.05)$. Komorbid hastalığı olan hastaların ASÖ-14 puan ortalamaları (26.36 \pm 6.77$)$, komorbid hastalığı olmayan hastalara (24.09 \pm 7.07$)$ göre yüksek olup aralarında anlamlı fark olduğu görüldü $(p<0.05)$ (Tablo 4).
Tablo 5. Hastaların kişilik ve Mi sonrası duygu durum özelliklerine göre ASÖ-14 puan ortalamaları $(n=300)$

\begin{tabular}{|c|c|c|c|c|}
\hline Kişilik özellikleri & Ort \pm SS & Min.-Maks. & $\mathbf{p}$ & $\mathbf{t}$ \\
\hline \multicolumn{5}{|l|}{ Yalnızlık korkusu } \\
\hline Evet & $25.66 \pm 7.23$ & $14-41$ & 0.658 & -0.443 \\
\hline Hayır & $26.05 \pm 6.72$ & $8-41$ & & \\
\hline \multicolumn{5}{|l|}{ Hobi varlığı } \\
\hline Evet & $24.75 \pm 6.87$ & $8-41$ & 0.003 & -2.973 \\
\hline Hayır & $27.07 \pm 6.68$ & $13-41$ & & \\
\hline \multicolumn{5}{|l|}{ İçe dönük } \\
\hline Evet & $26.36 \pm 6.78$ & $13-40$ & 0.473 & 0.719 \\
\hline Hayır & $25.75 \pm 6.90$ & $8-41$ & & \\
\hline \multicolumn{5}{|l|}{ Duygusal } \\
\hline Evet & $25.92 \pm 6.78$ & 8-39 & 0.964 & -0.055 \\
\hline Hayır & $25.96 \pm 6.96$ & $10-41$ & & \\
\hline \multicolumn{5}{|c|}{ Mi sonrası duygu durum } \\
\hline \multicolumn{5}{|c|}{ Endişeli } \\
\hline Evet & $27.33 \pm 6.79$ & $8-41$ & 0.001 & -3.268 \\
\hline Hayır & $24.76 \pm 6.72$ & $12-40$ & & \\
\hline \multicolumn{5}{|l|}{ Öfkeli } \\
\hline Evet & $26.00 \pm 7.69$ & $13-40$ & 0.937 & 0.080 \\
\hline Hayır & $25.92 \pm 6.63$ & $8-41$ & & \\
\hline \multicolumn{5}{|l|}{ Depresif } \\
\hline Evet & $25.75 \pm 7.36$ & $12-41$ & 0.811 & -0.240 \\
\hline Hayır & $25.99 \pm 6.74$ & $8-41$ & & \\
\hline \multicolumn{5}{|l|}{ Stresli } \\
\hline Evet & $26.01 \pm 6.88$ & $8-41$ & 0.841 & 0.201 \\
\hline Hayır & $25.85 \pm 6.86$ & $10-40$ & & \\
\hline
\end{tabular}

ASÖ: Algılanan Stres Ölçeği; Mi: Miyokard infarktüsü; n: katııımcı sayısı; Ort: Ortalama; SS: standart sapma; *: Independent Sample t Testi; **: One-way Anova; ***Post-hoc analizine göre farklılı̆ı yaratan gruplar.

\section{Mi Geçiren Hastaların ASÖ-14 Puanlarının Kişilik ve Mi Sonrası Duygu Durum Özelliklerine Göre Değerlendirilmesi}

Hobisi olmayan hastaların ASÖ-14 puan ortalaması (27.07 \pm 6.68$)$ hobisi olan hastalara $(24.75 \pm 6.87)$ göre daha yüksek ve aralarında anlamlı fark olduğu bulun$d u(p<0.05)$. Fiziksel aktivite yapmayan hastaların ASÖ14 puan ortalaması $(26.71 \pm 6.60)$ fiziksel aktivite yapan hastalara (24.95 \pm 7.07$)$ göre daha yüksek ve aralarında anlamlı fark olduğu tespit edildi $(p<0.05)$. Mi sonrası kendini endişeli olarak hisseden hastaların ASÖ-14 puan ortalaması (26.00 \pm 7.69$)$ endişeli hissetmeyen hastalara (24.76 \pm 6.72$)$ göre yüksek olup aralarında anlamlı fark olduğu görüldü $(p<0.05)$. Mi sonrası kendini öfkeli olarak hisseden hastaların puan ortalamaları, Mi sonrası kendini öfkeli, depresif ve stresli hissetme durumunun ASÖ14 puan ortalmasını etkilemediği tespit edildi ( $p>0.05$ ). Diğer kişilik özelliklerinin (yalnızlık korkusu, duygusal, içe dönük) algılanan stres düzeyini etkilemediği görüldü (p>0.05) (Tablo 5). 


\section{Tartışma}

Dünya genelinde ve ülkemizde başta gelen ölüm nedenleri arasında yer alan iskemik kalp hastalıklarından biri olan Mi önlenebilir bir hastalıktır. Değiştirilemeyen risk faktörlerinin yanı sıra değiştirilebilir risk faktörleri sayıca fazladır ve bunların çoğu davranış değişikliği ile düzeltilebilir. Stres değiştirilebilir risk faktörlerinden birisidir. Stresin kardiyovasküler hastalıklara yakalanma insidansını önemli düzeyde arttırdığı bilinmektedir. Stresin kontrol edilmesi veya azaltıcı girişimlerin uygulanması Mi sonrası gelişebilecek yeniden Mi geçirme olasılığını veya ani kardiyak ölüm gibi koroner olayların gelişmesini önleyebilir. Bu çalışmada, Mi geçirmiş hastalarda stres algısı ve stres algısını etkileyen faktörler incelenmiştir. Çalışmaya katılan hastaların yaş ortalaması $61.84 \pm 14$ olup büyük çoğunluğunu (\%67.3) erkek hastalar oluşturmaktadır. Türk Erişkinlerinde Kardiyovasküler Hastalık Risk Faktörleri (TEKHARF) çalışmasının 2017 yılı verilerine göre koroner kökenli ölüm insidansı erkekte yılda 5,7, kadında 3,6 seviyesinde bulunmuştur. ${ }^{[16]}$ Fırat ve Dedeli (2016)' nin, Mi geçiren hastalarda umutsuzluk ve yaşam kalitesini değerlendirdikleri çalışmalarında katılımcıların yaş ortalaması $57.4 \pm 11.0$ olup çoğunun erkek (\%77) hastalar olduğu belirlenmiştir. ${ }^{[17]}$ Özer ve ark. (2009)'nın Miyokart İnfarktüslü hastalarda anksiyete ve depresyonu incelediği başka bir çalışmada katılımcıların yaş ortalamasının $55.7 \pm 6.9$ olduğu ve çoğunun (\%60.7) erkek olduğu bulunmuştur. ${ }^{[18]}$ Bizim çalışmamız yukarıdaki çalışmaların bulguları ile paralellik göstermektedir. Çalışmamıza katılan hastaların ASÖ-14 puan ortalaması $25.94 \pm 6.86$ olup algılanan stres düzeyinin normal olduğu ve stres algısı sorularına ortalama bazen $(1,85)$ yanıtını verdiği belirlendi. Çalışmamızda kadınların stres algısı (26.15 \pm 6.91$)$ erkeklere $(25.50 \pm 6.76)$ göre daha yüksek bulundu fakat anlamlı bir fark görülmedi. Ülkemizde Mi geçirmiş hastaların algıladıkları stresi ölçen benzer bir çaIışma olmadığı için bizim verilerimizin doğrudan karşılaştırmasını yapmak mümkün değildir ancak yurt dışında yapılmış benzer iki çalışma ile değerlendirme yapabiliriz. Xu ve ark. (2015) yapmış olduğu akut Miyokard İnfarktüslü genç ve orta yaşlı hastalarda algılanan stres ve erken iyileşmede cinsiyet farklılıklarını belirledikleri çalışmalarında bizim çaIışmamızla benzer sonuçlar bulmuştur. Xu ve ark. (2015) erkeklerin ASÖ-14 puan ortalamasını $23.4 \pm 9.0$ ve kadınların ASÖ puan ortalamasını 27.0 \pm 9.9 olarak buduklarını belirtmişlerdir. Genel olarak, kadınların ölçekte yer alan 14 maddenin tamamında daha fazla stres algıladığını ortaya koymuşlardır. Kadınların algılanan stresi yansıtan olumsuz olarak ifade edilmiş durumları ereklerden daha sık, başa çıkma yeteneğini yansıtan olumlu olarak ifade edilen durumla$r$ ise erkeklerden daha az algıladıkları ifade edilmiştir. ${ }^{[19]}$
Aghei ve ark. (2015)'nın yapmış olduğu kanser ve koroner kalp hastalığı (KKH) hastalarında öfke yönetimi, anksiyete ve algılanan stresi karşılaştırdıkları bir başka çalışmada da benzer sonuçlar bildirilmiştir. ${ }^{[20]}$ Aghei ve ark. (2015) yapmış oldukları bu çalışmada kadınların ASÖ-14 ölçeğinde yer alan sorulara ortalama 3.32, erkeklerin ise 2.87 düzeyinde puan verdikleri belirtilmiştir. Çalışmaya katılan hastaların ölçekte yer alan ifadelerin her birine vermiş oldukları ortalama değerlere bakıldığında kadınların stres algısı durumunu oldukça veya çoğu zaman yaşadıklarını belirtmişlerdir. Erkeklerin ise stres algısı durumunu bazen veya oldukça yaşadıkları ifade edilmiştir. Bizim çalışmamızda da kadın hastaların algıladıkları stres erkek hastalara göre daha fazladır fakat arada anlamlı fark olmayıp her iki cinsin algıladığı stresin birbirine yakın olduğu görülmektedir. Xu ve ark. (2015) büyük ölçüde eşlik eden hastalıklar, fiziksel ve zihinsel sağlık durumu, aile içi çatışma, bakım verme talebi ve maddi zorluklardaki cinsiyet farklılıkları gibi nedenlerden dolayı algılanan stresin kadınlarda daha yüksek olabileceğini belirtmişlerdir. Aynı zamanda kadınlarda yüksek stres akut Mi sonrası 1 aylık dönemde erkeklerden daha kötü düzelme gösterdiğini, anjinaya özgü ve genel yaşam kalitesinin yanı sıra ruh sağlığı durumunda da belirgin şekilde daha kötü iyileşme ile ilişkilendirdiklerini ifade etmişlerdir. ${ }^{[19]}$ Çalışmamızda 18-65 yaş arası hastaların ASÖ-14 puan ortalaması 66 ve üstü yaş grubundaki hastalara göre daha yüksektir. Aynı şekilde $X u$ ve ark. (2015) da çalışmalarında genç orta yaş grubundaki hastaların ASÖ-14 puanını ileri yaştaki bireylere göre daha yüksek bulmuştur. Bizim çalışmamızda anlamlı fark bulunmazken bu çalışmada orta ve genç yaştaki bireylerle yaşlı grubu arasında algılanan strese yönelik anlamlı fark elde edilmiştir. Xu ve ark. (2015) 18-55 yaşları arasındaki bazal psikolojik stres ile akut Mi iyileşmesi arasında negatif ilişki bulmuşlardır. Kendi kendini algılayan stres ilerleyen yaşla ters orantılı olduğu için stresin genç yaşlarda akut Mi iyileşmesini etkilemede önemli bir rolünün olduğu bildirilmiştir. ${ }^{[19]}$ Bizim çalışmamızda okur yazar ve ilkokul mezunu bireylerin üniversite mezunlarına göre algıladıkları stres daha yüksek bulundu. Literatürdeki çalışmalarda ${ }^{[19,20]}$ hastaların büyük çoğunun eğitim seviyesi üniversite ve üstü olmasına rağmen her iki cinsiyette de stres algılarının bizim çalışmamızdaki bulgulara göre daha yüksek olduğunu görüyoruz. Bu çalışmaların yapıldığı ülkelerde toplumsal ihtiyaçların karşılanma politikaları, ekonomik refah düzeyi ve eğitim olanakları bizim ülkemize göre farklılıklar göstermektedir. Bu çalışmaların yapıldığı ülkelerde toplumun eğitim seviyesi zaten yüksek olduğu için örnekleme dahil edilen hastaların eğitim seviyeleri de daha yüksek bulunmuştur. Ülkemizde eğitim seviyesinin artması ile birlikte yaşam kalitesinin ve buna 
bağlı iş olanaklarının da arttığı düşünülürse eğitim seviyesi düşük olan bireylerde stres algısının ekonomik sıkıntılardan, bakmakla yükümlü oldukları aile üyelerinin ihtiyaçlarını karşılamada zorluk yaşadıklarından ve hastalığa uyumun daha az olmasından kaynaklandığı düşünülebilir. Bizim çalışmamızda aynı zamanda düşük gelirli hastaların stres algısı yüksek gelirli hastalara göre oldukça yüksek bulundu. Xu ve ark. (2015) çalışmalarında kadınların stres algısını erkeklere göre daha yüksek bulmalarının temel nedenini finansal kaynaklı olabileceğini belirtmişlerdir. Xu ve ark.'nın çalışmasında kadınların erkeklere göre daha büyük maddi sıkıntı yaşadıkları, saat karşılığı ücretlendirme ile çalıştırıldıkları ve yarı zamanlı çalışmanın bayanlarda daha yaygın olmasının yaşanan stresi arttırdığı belirtilmiştir. ${ }^{[19]}$ Düşük gelir toplumsal statünün, eğitim seviyesinin, sağlık hizmetlerinden yararlanmanın ve bakmakla yükümlü olunan aile bireylerinin ihtiyaçları ile birlikte bireysel intiyaçların karşılanmasını zorlaştırabileceği gibi yaşam kalitesini de düşürebilir ve buna bağlı düşük gelirli bireylerde daha yüksek düzeyde stres algılanabileceği düşünülmektedir. Çalışmamızda komorbid hastalığı olanların ve bu komorbid hastalıklardan diyabeti ve hipertansiyonu olanların algıladıkları stres anlamlı düzeyde yüksek bulundu. Bunlara ek olarak kalp yetersizliği olan hastalarda da anlamlı olmasa bile algılanan stres seviyesi daha yüksek bulundu. Xu ve ark. (2015) yapmış oldukları çalışmada kadınların algılanan stres puanının daha yüksek olmasının diğer nedenlerini kadınlarda erkeklere göre diyabet, kalp yetersizliği, böbrek yetersizliği ve kronik akciğer hastalığı gibi komorbid hastalıkların daha fazla bulunmasına bağlı olduğunu belirtmişlerdir. ${ }^{[19]}$ Bizim çalışmamızın bulguları yukarıdaki çalışmalarla paralellik göstermektedir. Komorbid hastalıklar, hastalığa uyumu ve birden fazla hastalığın yönetimini zorlaştırabileceği gibi bunlara bağlı da algılanan stresi arttırabilir. Bizim çalışmamızda düzenli ilaç kullanmayanların algıladıkları stres düzenli ilaç kullananlara göre anlamlı olarak yüksek bulundu. Mi geçirmiş bir bireyin hastalık yönetiminde başarılı olmasında ilaca uyumun önemli bir rolü vardır. Düzenli ilaç kullanımı hastanın daha az semptom yaşamasını sağlar ve hastaneye başvurusunu azaltır. Illaçların düzenli kullanılmaması öz bakımın azalmasına ve yaşam kalitesinin düşmesine neden olur. Bu durumlar algılanan stresin artmasında etkili olabilir. Çalışmamızda fiziksel aktivite yapmayan hastaların algıladıkları stres daha yüksek bulundu. Fiziksel aktivite yapanların stresle mücadelede daha başarılı oldukları ve algılanan stresin buna bağlı daha az olabileceği düşünülmektedir. Literatürde stres ve fiziksel egzersiz ilişkisi ile ilgili birçok çalışma ve derleme mevcuttur. Bunlara baktığımızda genel olarak düzenli ve düşük yoğunlukta yapılan fiziksel aktivitenin strese karşı vücudun oluşturduğu hormonal tepkiye giren organizmada dayanıklılığın arttığı ve stres yönetimine önemli katkısı olduğu bildirilmiştir. [21,22] Bu bilgiler çalışmamızın bulgularını desteklemektedir. Çalışmamızda hobisi olmayanların algıladıkları stres hobisi olanlara göre anlamlı düzeyde daha yüksek bulundu. Serbest zaman aktivitesi yani hobinin her yaş grubu için mutlu yaşamayı sağladığı, bedensel egzersiz ve bireyin kendine özgü hobi edinmesinin stres yönetimini kolaylaştırabileceği düşünülmektedir. Bizim çalışmamızda Mi sonrası yaşanan endişeli duygu durumunun da stresi arttırdığı görüldü. Kendini endişeli hisseden hastaların endişeli olmayanlara göre stres algısı daha yüksek bulundu. Endişe strese bağlı ortaya çıkan bir durum olarak düşünülürse algılanan stresin artmasında endişenin önemli bir yeri olduğunu söyleyebiliriz. Aghei ve ark. (2015) yapmış oldukları çalışmada koroner kalp hastalarında ve kanserli hastalarda algılanan stresle birlikte öfke yönetimi ve anksiyete düzeyini de incelemişlerdir. Bu çalışmada $\mathrm{KAH}^{\prime}$ da algılanan stresin ve öfkenin kanserli hastalara göre daha fazla olduğunu ve bu durumun KAH olan hastaların heyecanını ve endişlerini kontrol etmede dışsal öfke davranışlarını kullanmalarından kaynaklandığı bildirilmiştir. ${ }^{[19]}$ Bu veriler doğrultusunda endişenin algılanan stresi arttırabileceği düşünülmektedir.

\section{Sonuç}

Bu araştırma, Mi geçirmiş hastalarda algılanan stres düzeyinin ve algılanan strese etki eden faktörlerin belirlenmesi ile ilgili bulguları ortaya koymuş olup literatüre önemli bir katkı sağlamıştır. Bu çalışma sonucunda, Mi geçiren hastaların algıladıkları stres düzeyinin normal olduğu ve stresle başa çıkmada başarılı oldukları görülmüş olsa bile algılanan stres düşük gelir, komorbid hastalık, hipertansiyon, diyabet, düzenli ilaç kullanmamak, fiziksel aktivite yapmamak, hobinin olmaması ve Mi sonrası yaşanan endişe gibi faktörlere bağlı olarak arttığı sonucuna varıldı. Bu veriler doğrultusunda Mi geçiren hastaların stres düzeyini azaltıcı destek programlarının geliştirilmesi, hastalığın yönetimini kolaylaştırmak için multidisipliner ekip anlayışı ile sağlık hizmeti sunulması ve daha büyük hasta grupları ile yeni çalışmalar yapılması önerilmektedir.

\section{Teşekkür}

Araştırmamızın yürütülmesine katkı sağlayan, bilgilerini bizimle içtenlikle paylaşan ve çalışmaya katılmayı gönüllü olarak kabul eden tüm hastalara teşekkür ederiz.

Etik Kurul Onayı: Marmara Üniversitesi Sağlık Bilimleri Enstitüsü Klinik Araşstırmalar Etik Kurulu'ndan (Onay Tarihi ve Sayısı: 17.12.2018-231) etik kurulu izni ve kurum izni alınarak gerçekleştirildi. 
Hakem Değerlendirmesi: Dış bağımsız.

Çıkar Çatışması: Yazarlar arasında herhangi bir çıkar çatışması bulunmamaktadır.

Yazarlık Katkıları: Konsept: B.B., S.O.; Dizayn: B.B., S.O.; Veri Toplama veya İşleme: S.A., B.C., S.K., B.K., G.A.; Analiz veya Yorumlama: B.B.; Literatür Arama: B.B.; Yazan: B.B.

\section{Kaynaklar}

1. World Health Organization The top 10 causes of death (2018) (erişim tarihi: 2 Kasım 2019). https://www.who.int/news-room/fact-sheets/detail/the-top-10-causes-of-death

2. Türkiye İstatistik Kurumu Ölüm Nedeni İstatistikleri Haber Bülteni Sayı: 3062626 Nisan 2019 (2018). http://www.tuik.gov.tr/ PreTablo.do?alt_id=1083

3. Thygesen K, Alpert JS, Jaffe AS, Simoons ML, Chaitman BR and White CHD. Third Universal Definition of Myocardial Infarction. Journal of the American Heart Association Circulatin 2012;126:2020-35.

4. Arslan H, Arkar H, Danaoğlu Z. Mlyokard İnfarktüsü Geçiren Kişilerde Mi̇zaç ve Karakter Boyutları, Öfke, Anksiyete ve Depresyon Düzeyleri. Klinik Psikiyatri Dergisi 2011;14:143-49.

5. Oğuz S, Erguvan B, Ünal G, Bayrak B, Çamcı G. Üniversite Öğrencilerinde Kardiyovasküler Hastalıklar Risk Faktörleri Bilgi Düzeyinin Belirlenmesi. MN Kardiyoloji 2019;26:184-91.

6. Oğuz S, Bayrak B, Genç A, Çamcı G. The Effect of Sad Text on Blood Pressure. Pakistan Heart Journal 2018;51:204-10.

7. Oğuz S, Cesur K, Koç S. Hemşirelik Öğrencilerinde Koroner Kalp Hastalığı Risk Faktörlerinin Belirlenmesi. Türk Kardiyoloji Derneği Kardiyovasküler Hemşirelik Dergisi 2011;4:18-21.

8. Gerrig RJ, Zimbardo, Phillip G. Psychology and life Çeviren: Sart G. Psikoloji ve Yaşam.19.basım, Nobel AkadeMik Yayıncılık Eğitim Danışmanlık Ankara 2012;380-382.

9. Türk Kardiyoloji Derneği Koroner Arter Hastalığına Yaklaşım ve Tedavi Kılavuzu (Erişim tarihi: 1.11.2019) https://www.tkd. org.tr/kilavuz/k06/207d6.htm?wbnum=1302

10. Eskin M, Harlak H, Demirkıran F, Dereboy Ç. Algılanan Stres Ölçeğinin Türkçeye Uyarlanması: Güvenirlik ve Geçerlik Analizi. Yeni Symposium Journal 2013;51:132-40.

11. Reiter RJ, Tan DX. Melatonin: A Novel Protective Agent Against Oxidative İnjury of The İscheMic-Reperfused Heart. Cardiovas- cular Res 2003;58:10-19.

12. Melle V, De Jonge JP, Spijkerman PD, Tijssen TA, Ormel JGP, Veldhuisen VJ, Prognostic Association of Depression Following Myocardial Infarction with Mortality and Cardiovascular Events: A Meta Analysis. Psychosomatic Medicine 2004;66:814-22

13. Pedersen S, Middel B, Larsen LM. The Role of Personality Variables and Social Support in Distress and Perceived Health in Patients Following Myocardial Infarction. Journal of Psychosomatic Research 2002;53:1171-75.

14. Durna U. Stres, A ve B Tipi Kişilik Yapısı ve Bunlar Arasındaki İlişki Üzerine Bir Araştırma. Yönetim ve Ekonomi Dergisi 2004:11;191-206.

15. Özer C, Kalav Z. Cardiac Nursing in Turkey and in the World. Turk J Card Nur 2016;7:2-14.

16. Onat A, Can G, Yüksel H, Ademoğlu E, Ünaltuna EN, Kaya A, Altay S. TEKHARF 2017 Tıp Dünyasının Kronik Hastalıklara Yaklaşımına Öncülük. Logos Yayıncılık İstanbul 2017;1-304. http:// file.tkd.org.tr/PDFs/TEKHARF-2017.pdf

17. Fırat FA, Dedeli Ö. Miyokart İnfarktüsü Geçiren Hastalarda Umutsuzluk ve Yaşam Kalitesinin Değerlendirilmesi. Journal of Cardiovascular Nursing 2016;7:153-61.

18. Özer ZC, Şenuzun F, Tokem Y. Mlyokart İnfarktüslü Hastalarda Anksiyete ve Depresyonun İncelenmesi. Türk Kardiyol Dern Arş - Arch Turk Soc Cardiol 2009;37:557-56.

19. Xu X, Bao H, Strait K, Spertus JA, Lichtman JH, D'Onofrio G, Spatz E, Bucholz EM, Geda M, Lorenze NP, Bueno H, Beltrame JF and Krumholz HM. Sex Differences in Perceived Stress and Early Recovery in Young and Middle-Aged Patients with Acute Myocardial Infarction. Circulation 2015;17:131(7): 614-623.

20. Aghei M, Ghorbani N, RostaMi R, Mahdavi A. Comparison of anger management, anxiety and perceived stress in patients with cancer and Coronary Heart Disease (CHD). J Med Life 2015;8:97-101.

21. Civan A, ÖzdeMir İ, Gencer YG, Durmaz M. Egzersiz ve Stres Hormonları. Türkiye Spor Bilimleri Dergisi 2018;2:1-14.

22. Yeltepe H, Yargıç IL. Egzersiz ve Stres. Turkiye Klinikleri Psychiatry 2011;4:51-8.

23. Güçlü N. Stres YönetiMi. G.Ü. Gazi Eğitim Fakültesi Dergisi 2001;21:91-109. 